\title{
FANCC wt Allele
}

National Cancer Institute

\section{Source}

National Cancer Institute. FANCC wt Allele. NCI Thesaurus. Code C86028.

Human FANCC wild-type allele is located in the vicinity of $9 q 22.3$ and is approximately 219 $\mathrm{kb}$ in length. This allele, which encodes Fanconi anemia group $\mathrm{C}$ protein, may be involved in the mediation of both DNA repair and cell cycle progression. Mutation of the gene is associated with Fanconi anemia. 